\title{
Maximal Diffusing Capacity of the Lung for Carbon Monoxide *
}

\author{
Robert L. Johnson, Jr., † Harold F. Taylor, $\ddagger$ and W. Harold Lawson, Jr.,§ \\ With the technical assistance of Abraham Prengler
}

(From the Cardiopulmonary Division, Department of Internal Medicine, University of Texas Southwestern Medical School, Dallas, Texas)

During exercise pulmonary diffusing capacity for carbon monoxide and oxygen increases because the pulmonary capillary bed expands (1). It seems reasonable that there should be an upper limit to this expansion at which the diffusing capacity reaches maximum. The apparent oxygen diffusing capacity $\left(\mathrm{DL}_{\mathrm{O}_{2}}\right)$ has been noted to approach a plateau or upper limit as the work load increases $(2,3)$, but a similar plateau for CO diffusing capacity has never been clearly demonstrated $(1,4)$ perhaps because it has not been measured at heavy enough work loads. Thus our purpose was to determine how high CO diffusing capacity can go as exercise work load increases and to see whether it reaches a plateau before the maximal tolerated work load is achieved.

To accomplish this we measured apparent $\mathrm{CO}$ diffusing capacity $\left(\mathrm{DL}_{\mathrm{CO}}\right)$ and pulmonary blood flow simultaneously in five normal adults, five normal children, and in three adult patients with mitral stenosis. Measurements were made at rest and at increasing treadmill work loads up to and beyond that causing maximal oxygen consumption. At rest and at maximal oxygen consumption the true membrane diffusing capacity for $\mathrm{CO}\left(\mathrm{DM}_{\mathrm{CO}}\right)$ and the pulmonary capillary blood volume (Vc) were estimated by the RoughtonForster method (5).

* Submitted for publication September 10, 1964; accepted November 5, 1964.

Supported by grants from the U. S. Public Health Service (HE 07744 and HE 06296).

† Address requests for reprints to: Dr. Robert L. Johnson, Jr., University of Texas Southwestern Medical School, Dallas, Texas 75235.

$\ddagger$ Work performed during a fellowship from the U. S. Public Health Service.

§ Work performed during a fellowship from the American Thoracic Society.

\section{Methods}

First we determined the maximal work load that each subject could tolerate on a motor-driven treadmill. We tried to push each subject beyond that work load, which resulted in the maximal oxygen consumption as defined by Mitchell, Sproule, and Chapman (6). Expired air was collected for measuring oxygen consumption between $1 \frac{1}{1}$ and $2 \frac{1}{2}$ minutes after starting exercise. The mixed expirate was analyzed with a Pauling oxygen analyzer and an infrared $\mathrm{CO}_{2}$ analyzer calibrated before each analysis with standard mixtures of oxygen, nitrogen, and $\mathrm{CO}_{2}$. Heart rates were recorded by EKG on a Grass recorder.

Dioo and pulmonary capillary blood flow (Qc) were measured simultaneously from the uptake of $\mathrm{CO}$ and $\mathrm{C}_{2} \mathrm{H}_{3}$ during breath holding as previously described in detail by Johnson, Spicer, Bishop, and Forster (1). The method combines the breath-holding technique of Ogilvie, Forster, Blakemore, and Morton for DLco (4) with that of Cander and Forster for Qc (7). A gas chromatograph was used to perform the gas analyses as described by Lawson and Johnson (8).

DLco, Q́c, and pulmonary tissue volume were estimated at rest from the line best fitting the exponential disappearance of $\mathrm{CO}$ and acetylene during separate breathholding intervals of approximately $3,7,10$, and $15 \mathrm{sec}-$ onds. DLoo and $\dot{Q}_{c}$ at exercise are averages of three or more single breath measurements ( 5 to 10 seconds of breath holding); Q $c$ was calculated assuming that pulmonary tissue volume was the same during exercise as it was at rest. Measurements were duplicated at a high and at a low alveolar oxygen tension (i.e., at approximately 140 and $620 \mathrm{~mm} \mathrm{Hg}$ ) so that both Vc and $\mathrm{DMco}$ could be estimated by the method of Roughton and Forster (5). The latter authors have indicated that the following relationship exists between $\mathrm{DL}_{\mathrm{C}_{0}}$ and $\mathrm{DM}_{\mathrm{M}}$ :

$$
\left\{\begin{array}{c}
1 / \text { DLco }=1 / \text { DMco }+1 / \theta_{\mathrm{coV}} \\
\left.\begin{array}{c}
\text { total } \\
\text { resistance }
\end{array}=\underset{\text { resistance }}{\text { membrane }}+\begin{array}{c}
\text { red cell } \\
\text { resistance }
\end{array}\right),
\end{array}\right.
$$

where $\theta_{\infty}=$ the specific rate in milliliters per minute times millimeters $\mathrm{Hg}$ at which $\mathrm{CO}$ dissolved in plasma can be absorbed by the red cells in $1 \mathrm{ml}$ of whole blood if the blood has an oxygen capacity of $20 \mathrm{ml}$ of oxygen per $100 \mathrm{ml}$ of blood. Since $\mathrm{CO}$ and oxygen compete for the intracorpuscular hemoglobin, the red cell resistance to $\mathrm{CO}$ uptake increases as the oxygen tension within the 
TABLE I

Normal subjects

\begin{tabular}{|c|c|c|c|c|c|c|c|}
\hline Subject & Sex & Age & Height & Weight & $\begin{array}{l}\text { Total } \\
\text { lung } \\
\text { capacity* }\end{array}$ & $\begin{array}{c}\text { Maximal } \\
\text { oxygen } \\
\text { consump- } \\
\text { tion }\end{array}$ & $\underset{\text { heart }}{\text { rate }}$ \\
\hline & & years & $m$ & $k g$ & $L$ (BTPS $\dagger)$ & $\mathrm{ml} / \mathrm{min} / \mathrm{kg}$ & beats/min \\
\hline SD & $F$ & 8 & 1.33 & 30.9 & 2.53 & 47.2 & 202 \\
\hline TE & $\mathrm{M}$ & 9 & 1.33 & 29.5 & & 51.9 & 200 \\
\hline RB & $\mathbf{F}$ & 10 & 1.48 & 35.0 & 4.19 & 48.3 & 212 \\
\hline $\mathrm{JH}$ & $\mathrm{F}$ & 12 & 1.48 & 43.6 & 4.56 & 47.2 & \\
\hline $\mathrm{LM}$ & $\mathrm{F}$ & 15 & 1.67 & 48.6 & & 41.8 & \\
\hline WH & $\mathrm{M}$ & 18 & 1.73 & 74.1 & 6.16 & 49.3 & 175 \\
\hline $\mathrm{JH}$ & $\mathbf{M}$ & 20 & 1.70 & 60.0 & 5.15 & 45.7 & 185 \\
\hline JV & $\mathbf{M}$ & 21 & 1.63 & 59.1 & 4.85 & 44.7 & 168 \\
\hline ES & $\mathbf{M}$ & 23 & 1.80 & 74.5 & 6.18 & 44.8 & 182 \\
\hline$\overline{\mathrm{HL}}$ & $\mathbf{M}$ & 27 & 1.82 & 73.6 & 5.91 & 47.0 & \\
\hline $\mathrm{PC}$ & $\mathrm{F}$ & 28 & 1.70 & 61.8 & 5.39 & 32.0 & \\
\hline
\end{tabular}

* Measured by open-circuit nitrogen washout.

$\dagger$ Body temperature, pressure, saturated with water.

red cell increases; thus at high alveolar oxygen tensions DLco becomes less. If the relationship between $\mathrm{Po}_{2}$ and $1 / \theta_{\mathrm{co}}$ is known, it is possible to estimate $\mathrm{DM}_{\mathrm{co}}$ and Vc from measurements of DLco at two or more alveolar oxygen tensions. The relationship between $1 / \theta_{\text {co }}$ and oxygen tension has been measured in vitro and lies within the following range of uncertainty (5): $1 / \theta_{\mathrm{co}}=0.33+0.0058$ $\mathrm{Po}_{2}$, and $1 / \theta_{\mathrm{Co}}=1.00+0.0058 \mathrm{Po}_{2}$. To estimate $\mathrm{DM}_{\mathrm{Mco}}$ and $\mathrm{Vc}$ we have assumed an intermediate relationship between $1 / \theta_{\mathrm{co}}$ and $\mathrm{Po}_{2}$ (i.e., $1 / \theta_{\mathrm{co}}=0.73+0.0058 \mathrm{Po}_{2}$ ) (1).

DLco changes with changes in pulmonary blood flow under certain conditions (1) ; therefore, whenever pulmonary capillary blood flow measured while the subject was breathing air differed from that while he was breathing oxygen by more than $10 \%$ of the higher blood flow, membrane diffusing capacity and capillary blood volume were not calculated. This precaution helps to insure that measurements of $D_{L_{c o}}$ made at different oxygen tensions are comparable. DLco was corrected for the accumulation of carboxyhemoglobin in mixed venous blood as previously described $(1,9)$.

Vital capacities were measured with a Stead-Wells spirometer, and functional residual volume was estimated from the nitrogen washed out of the lungs during 7 minutes of oxygen breathing. Breath-holding measurements were made at or near total lung capacity.

\section{Results}

Table I describes the normal subjects and gives the maximal oxygen consumption of each in milliliters per minute per kilogram of body weight. Maximal oxygen consumption was achieved by each subject according to the criteria of Mitchell, Sproule, and Chapman (6).

Table II provides a description of the patients with mitral stenosis. In two of these patients the diagnosis was established by cardiac catheterization and confirmed at surgery. In the remaining patient the diagnosis had to be made on clinical grounds since the patient refused catheterization. Maximal oxygen consumptions of these patients were significantly lower than those predicted.

The essential results are given in Figure 1 and

TABLE II

Patients with

\begin{tabular}{|c|c|c|c|c|c|c|c|c|}
\hline Patient & Sex & Age & Height & Weight & & $\begin{array}{l}\text { lng } \\
\text { ty }\end{array}$ & $\underset{\text { const }}{\text { Maxim }}$ & $\begin{array}{l}\text { xygen } \\
\text { tion }\end{array}$ \\
\hline $\begin{array}{l}1 \\
2 \\
3\end{array}$ & $\begin{array}{l}F \\
F \\
F\end{array}$ & $\begin{array}{l}25 \\
33 \\
25\end{array}$ & $\begin{array}{l}m \\
1.65 \\
1.65 \\
1.57\end{array}$ & $\begin{array}{c}\text { kg } \\
57.3 \\
66.4 \\
49.5\end{array}$ & $\begin{array}{c}L \\
5.90 \\
5.08 \\
3.54\end{array}$ & $\begin{array}{c}\% \text { pred. } † \\
119 \\
103 \\
83\end{array}$ & $\begin{array}{c}/ \min / \mathbf{k g} \\
19.4 \\
19.6 \\
13.7\end{array}$ & $\begin{array}{c}\text { \% pred. } \\
53 \\
57 \\
38\end{array}$ \\
\hline
\end{tabular}

* MS = mitral stenosis $; \mathrm{MI}=$ mitral insufficiency.

$\dagger$ Predicted from the formula of Needham, Rogan, and McDonald (10).

¥ Predicted from Andersen's data (11). 
in Tables III and IV and may be summarized as follows:

1) At maximal oxygen consumption the average arterial-venous difference in oxygen content (15.5 \pm 1.7 ) estimated indirectly from pulmonary capillary blood flow during breath holding (Table III) is not significantly different from the a-v oxygen difference at maximal oxygen consumption (14.3 \pm 2.5 ) measured by Mitchell, Sproule, and Chapman (6) during normal breathing $(\mathrm{p} \sim 0.1)$. This is evidence that the breath-holding maneuver used for our measurements did not significantly alter pulmonary capillary circulation at heavy exercise.

2) In normal subjects $D L_{c o}$ increased as the work load increased and reached a plateau at approximately the same work load at which blood flow and oxygen consumption reached peak levels (Figure 1).

3) $\mathrm{DL}_{\mathrm{Co}}$ increased owing to a twofold increase in Vc and a $20 \%$ increase in $\mathrm{DM}_{\mathrm{Co}}$ (Table III). Vc does not appear to expand further when the work load exceeds that causing maximal oxygen consumption and maximal cardiac output (Table IV).

4) In the patients with mitral stenosis Vc was larger than normal at rest (Figure 2), presumably owing to higher pulmonary capillary pressures; during exercise Vc did not increase much above that at rest, and in no instance did Vc exceed the normal upper limit (Figure 2).

\section{Discussion}

Our results confirm those of Newman, Smalley, and Thomson (13) that $\mathrm{DL}_{\mathrm{co}}$ continues to increase with increasing work load until maximal oxygen consumption is reached. However, as exercise work load increases beyond that causing maximal oxygen consumption, neither $\mathrm{DL}_{\mathrm{co}}$ nor $\mathrm{Vc}$ increases further. This does not mean necessarily that the maximal potential volume of the pulmonary capillary bed has been reached. The capillary bed might expand further if pulmonary blood flow could go higher or if capillary blood pressure could be increased by some other means. Left atrial pressure is an important determinant of capillary pressure in the lungs, and if the capillary bed were capable of further expansion, an abnormally high left atrial pressure should cause Vc to exceed the peak volume measured in normal subjects during exercise (14-17). However, in the present investigation the pulmonary capillary blood volumes were no greater in three patients with mitral stenosis working at full capacity than in normal subjects exercising (Figure 2), and the results obtained by other investigators who have measured Vc in patients with pulmonary congestion (15-17) are in essential agreement with our own (Figure 3 ). Furthermore, it has not been possible artificially to induce pulmonary congestion in normal subjects severe enough to make the pulmonary capillary bed expand more than it normally does at heavy exercise. Ross, Maddock, and Ley (18) have induced pulmonary congestion in normal subjects by G-suit inflation. Lewis, McElroy, Hayford-Welsing, and Samberg (19) have done the same by intravenous infusions of norepinephrine in normal subjects both upright and supine. The largest increase in pulmonary capillary blood volume reported from these latter two studies was 1.9 times the control value, which is about the same increase as that normally observed from rest to peak exercise. The findings

TABLE II

mitral stenosis

\begin{tabular}{|c|c|c|c|c|c|c|}
\hline \multirow{3}{*}{$\begin{array}{c}\text { Maximal } \\
\text { heart } \\
\text { rate }\end{array}$} & \multicolumn{4}{|c|}{ Cardiac catheterization at rest } & \multirow[b]{3}{*}{ Diagnosis* } & \multirow[b]{3}{*}{$\begin{array}{c}\text { Clinical } \\
\text { grade }\end{array}$} \\
\hline & \multirow[b]{2}{*}{$\begin{array}{l}\text { Cardiac } \\
\text { output }\end{array}$} & \multicolumn{3}{|c|}{ Pulmonary arterial pressure } & & \\
\hline & & $\begin{array}{l}\text { Systolic/ } \\
\text { Diastolic }\end{array}$ & Mean & Wedge & & \\
\hline & $L / \min$ & & $m m \mathrm{Hg}$ & & & \\
\hline 144 & 7.20 & $43 / 24$ & 31 & & $\begin{array}{l}\text { MS } \\
\text { MS }\end{array}$ & II \\
\hline 175 & 3.08 & $99 / 48$ & 64 & 35 & MS and MI & IV \\
\hline
\end{tabular}


TABLE III

Pulmonary capillary blood flow $\left(\dot{Q}_{c}\right)$, volume $(V c)$, and membrane diffusing capacity (DMco)

\begin{tabular}{|c|c|c|c|c|c|c|c|c|}
\hline \multirow[b]{2}{*}{ Subject } & \multicolumn{4}{|c|}{ At rest } & \multicolumn{4}{|c|}{ At maximal $\mathrm{O}_{2}$ consumption } \\
\hline & $\mathrm{VA}^{*}$ & Q’c & Vc & DM⿻o & VA* & $\grave{Q c}$ & Vc & DMco \\
\hline & $L$ & $L / \min$ & $m l$ & $\frac{m l / m i n}{m m B g}$ & $L$ & $L / \min$ & $m l$ & $\frac{m l / m i n}{m m B g}$ \\
\hline SD & 2.01 & 4.6 & 42 & 34 & 2.41 & 11.1 & 101 & 37 \\
\hline TE & 2.48 & 3.1 & 48 & 30 & 2.27 & 10.2 & 81 & 41 \\
\hline RB & 3.58 & 4.4 & 82 & 37 & 3.86 & 10.8 & 112 & 60 \\
\hline $\mathrm{JH}$ & 3.95 & 5.8 & 87 & 59 & 3.70 & 12.0 & 173 & 48 \\
\hline LM M & 3.72 & 5.8 & 71 & 47 & 3.86 & 12.9 & 128 & 59 \\
\hline$\overline{\mathrm{WH}}$ & 6.10 & 6.8 & 110 & 72 & 6.11 & 21.1 & 182 & 116 \\
\hline $\mathrm{JH}$ & 5.23 & 5.7 & 80 & 72 & 5.11 & 20.4 & 170 & 84 \\
\hline JV & 5.20 & 5.4 & 63 & 59 & 4.65 & 16.6 & 131 & 73 \\
\hline ES & 6.27 & 6.7 & 77 & 85 & 5.65 & 24.2 & 215 & 79 \\
\hline $\mathrm{HL}$ & & & & & 5.91 & 18.6 & 200 & 97 \\
\hline PC & 5.11 & 4.7 & 86 & 64 & 4.89 & 13.8 & 175 & 87 \\
\hline Average & & & & & & & & \\
\hline Normal & 4.36 & 5.3 & 75 & 56 & 4.40 & 15.6 & 167 & 71 \\
\hline $\begin{array}{l}\text { Patient } 1 \\
\text { Patient } 2\end{array}$ & $\begin{array}{l}5.91 \\
4.26\end{array}$ & 7.6 & 136 & 53 & 5.70 & $\begin{array}{r}10.9 \\
70\end{array}$ & 177 & $\begin{array}{l}57 \\
37\end{array}$ \\
\hline Patient 3 & $\begin{array}{l}4.20 \\
3.58\end{array}$ & $\begin{array}{l}0.3 \\
4.6\end{array}$ & 111 & $\begin{array}{l}31 \\
26\end{array}$ & 3.66 & $\begin{array}{l}1.9 \\
5.4\end{array}$ & 131 & 25 \\
\hline
\end{tabular}

${ }^{*} \mathrm{~V}_{\mathrm{A}}=$ alveolar volume measured from the single-breath neon dilution.

suggest that the normal pulmonary capillary bed may be approaching or may have reached the upper limit of distensibility at peak exercise. This conclusion is further substantiated by the anatomical estimates of pulmonary capillary blood volume made by Weibel (20).

Weibel has counted the number of capillaries in representative parts of inflated and fume-fixed
W.H.

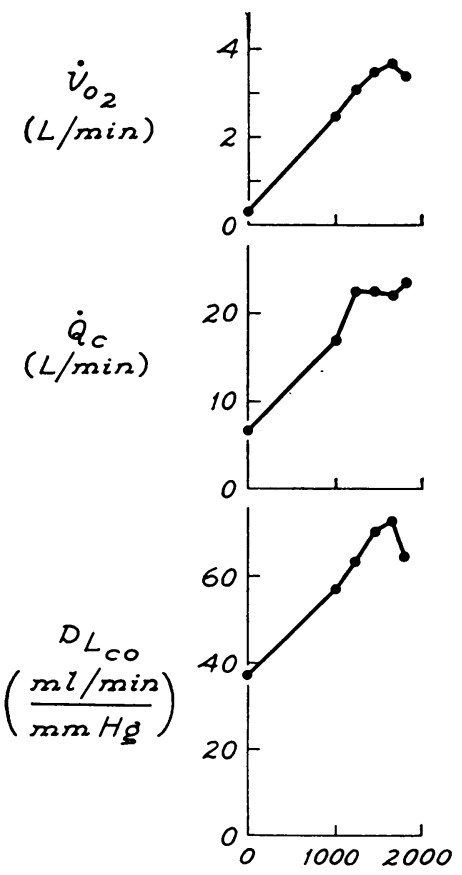

J.H.
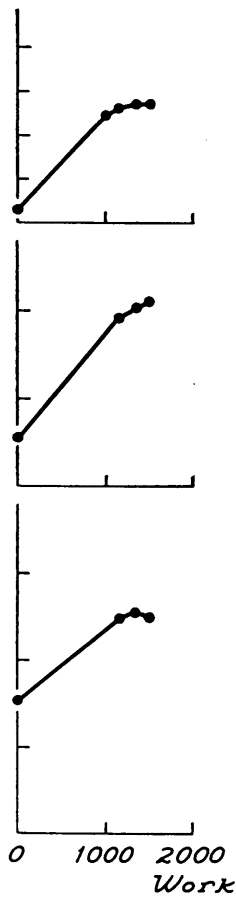

J.V.
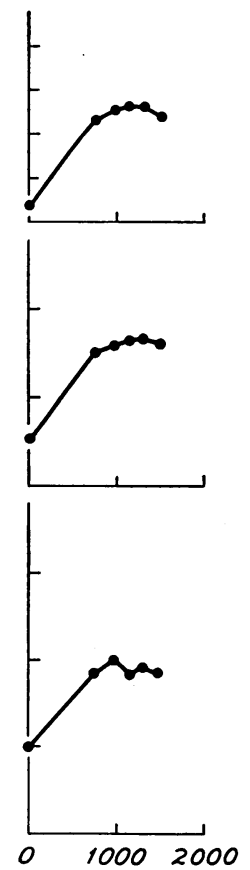

E.S.
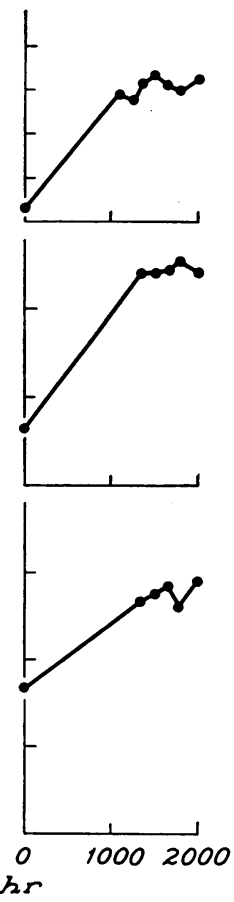

H.L.

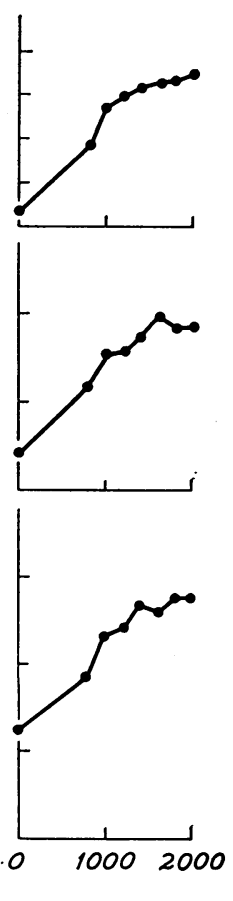

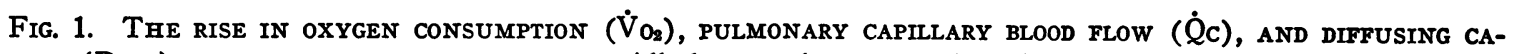
PACITY ( $\mathrm{DL}_{\mathrm{L} O}$ ) wITH INCREASING wORK LOADS. All three tend to approach peak levels at the same work loads. 
TABLE IV

Pulmonary capillary blood flow $(\dot{Q} c)$, volume $(V c)$, and membrane diffusing capacity

(DMco) at maximal oxygen consumption and at a heavier work load

\begin{tabular}{|c|c|c|c|c|c|c|c|c|c|c|}
\hline \multirow[b]{2}{*}{ Subject } & \multicolumn{5}{|c|}{ At maximal oxygen consumption } & \multicolumn{5}{|c|}{ Beyond maximal oxygen consumption } \\
\hline & Load* & V́ont & $\dot{Q} c$ & Vc & Dacoo & Load* & $\dot{\text { Vost }}$ & $\dot{Q} c$ & Vc & Dм⿻ \\
\hline $\begin{array}{c}\text { TE } \\
\text { JH } \\
\text { JV } \\
\text { ES } \\
\text { Average }\end{array}$ & $\begin{array}{r}k c a l / h r \\
620 \\
1,326 \\
1,294 \\
1,490 \\
1,182\end{array}$ & $\begin{array}{c}L / \min \\
1.58 \\
2.72 \\
2.62 \\
3.33 \\
2.56\end{array}$ & $\begin{array}{c}L / \min \\
10.2 \\
20.4 \\
16.6 \\
24.2 \\
17.8\end{array}$ & $\begin{array}{r}m l \\
81 \\
170 \\
131 \\
215 \\
149\end{array}$ & $\begin{array}{c}m l / m i n \\
m m H_{g} \\
41 \\
84 \\
73 \\
79 \\
69\end{array}$ & $\begin{array}{r}k c a l / h r \\
679 \\
1,482 \\
1,460 \\
1,996 \\
1,404\end{array}$ & $\begin{array}{c}L / \min \\
1.43 \\
2.62 \\
2.41 \\
3.28 \\
2.44\end{array}$ & $\begin{array}{c}L / \min \\
9.6 \\
21.1 \\
16.2 \\
24.2 \\
17.8\end{array}$ & $\begin{array}{c}m l \\
74 \\
198 \\
133 \\
198 \\
151\end{array}$ & $\begin{array}{c}m b / m i n \\
m m H g \\
40 \\
76 \\
71 \\
86 \\
68\end{array}$ \\
\hline
\end{tabular}

* Work loads were estimated from the grade and speed at which the subject ran using the nomogram of Margaria Cerretelli, Aghemo, and Sassi (12).

$\dagger \dot{\mathrm{Vo}}=$ oxygen consumption.

post-mortem lungs, measured the capillary diameters, and estimated the amount of blood that the capillary bed could hold if all the capillaries were completely filled to the point of being circular cylinders. The normal capillary bed of the lung expands during heavy exercise to about the same volume as that estimated by Weibel for a completely filled capillary bed (Figure 3 ). The latter observation also suggests that the pulmonary capillary bed expands simply by filling up rather than by capillaries being stretched to larger diameters. As suggested by Cotes, Snidal, and Shepard (21), the lung capillaries may fill from collapsed or el- liptical cylinders at rest to circular cylinders during exercise without their walls being stretched and with little or no change in membrane diffusing capacity. Further radial expansion of a capillary beyond this point of complete filling would require stretching of the capillary walls and very likely high distending pressures, since according to the Laplace relationship the elastic recoil in the wall of a small capillary has a considerable mechanical advantage for resisting distention (i.e., tension in the wall of a cylinder = distending pressure $X$ radius). Thus it is possible that Weibel's anatomical estimates of Vc represent the

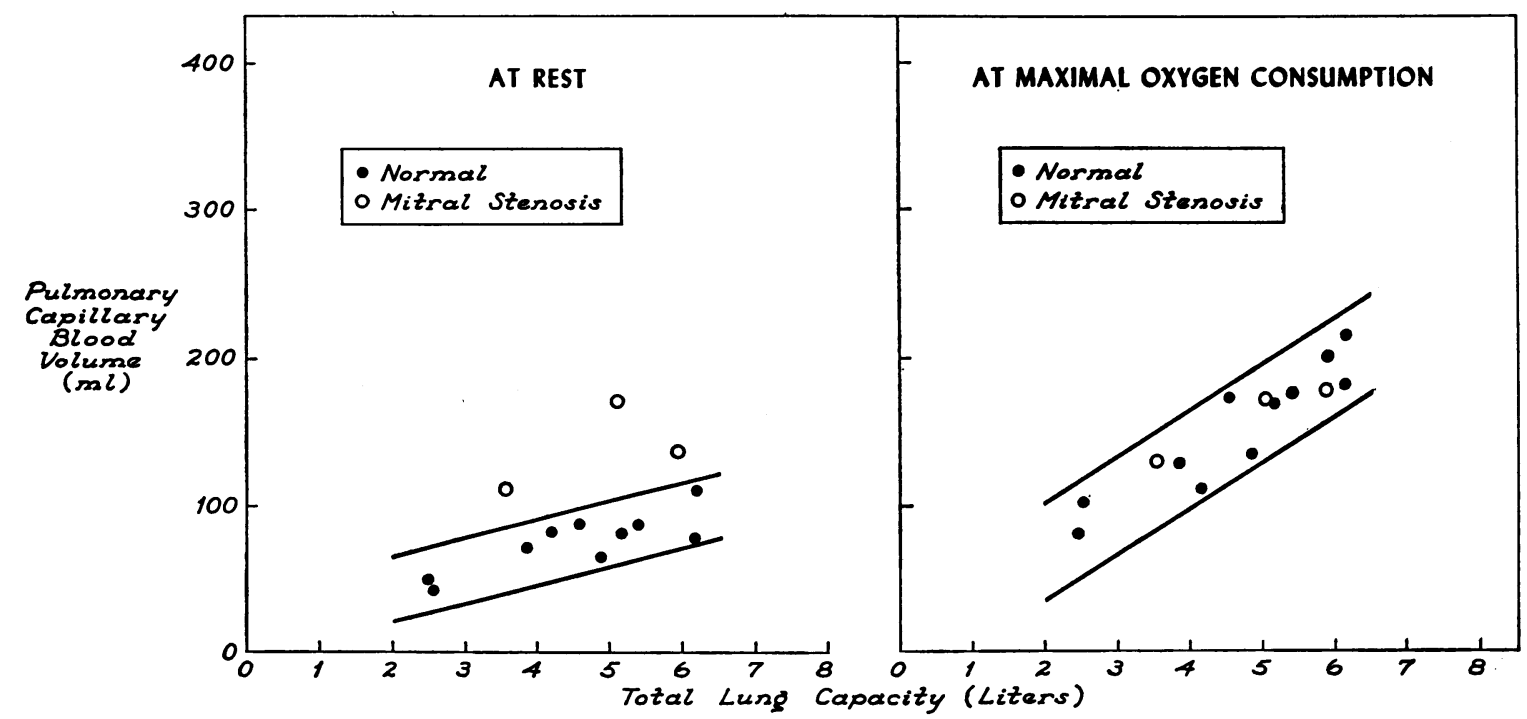

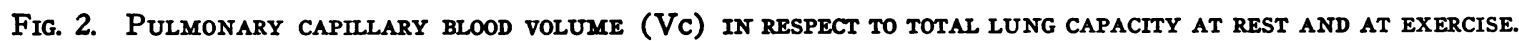
The solid lines represent $2 \mathrm{SE}$ on either side of the normal regression line. At rest the pulmonary capillary blood volumes of the patients with mitral stenosis were consistently above normal, presumably as a consequence of the higher capillary pressures in the patients; at peak exercise expansion of the pulmonary capillary bed in the patients did not exceed that found in the normal subjects. 


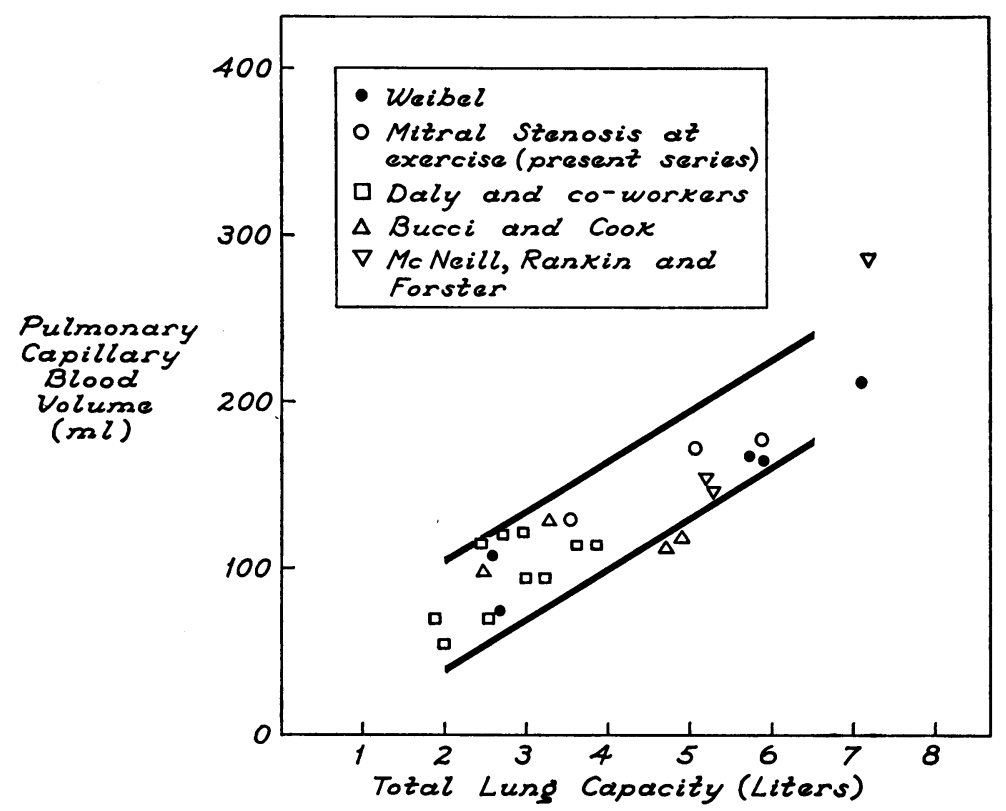

Fig. 3. Anatomical estimates of pulmonary Capillary blood volume (VC) COMPARED TO PHYSIOLOGIC ESTIMATES IN PATIENTS WITH PULMONARY CONGESTION AND IN NORMAL SUBJECTS AT HEAVY EXERCISE. The solid lines represent $2 \mathrm{SE}$ on either side of the regression line for normal subjects at heavy exercise (Figure 2). The anatomical estimates of Vc are within the same range as those found by physiologic measurements in normal subjects at peak exercise and in patients with pulmonary congestion. The patients with pulmonary congestion studied by Daly and co-workers (14) had mitral stenosis and as a group had an average left atrial pressure of $23 \mathrm{~mm} \mathrm{Hg}$. The patients studied by Bucci and Cook had high pulmonary blood flows due to interatrial septal defects plus some associated obstruction to left ventricular filling (15). One of the patients studied by McNeill, Rankin, and Forster (16) had left ventricular failure due to hypertension, one had mitral stenosis, and one an atrial septal defect. The results are compatible with the hypothesis that the pulmonary capillary bed approaches its maximal potential volume at peak exercise and cannot be distended significantly more by higher capillary pressures.

physiologic upper limit of pulmonary capillary blood volume and that the pulmonary capillary bed fills to this volume only at very heavy work loads.

\section{Summary}

The purpose of this investigation was to determine how much the apparent CO diffusing capacity $\left(\mathrm{DL}_{\mathrm{CO}}\right)$ increases from rest to peak exercise and whether it reaches a plateau with increasing work load. Pulmonary capillary blood flow and apparent $\mathrm{CO}$ diffusing capacity were measured by a breath-holding technique both at rest and during exercise and repeated at two different alveolar oxygen tensions so that the true membrane dif- fusing capacity $\left(\mathrm{DM}_{\mathrm{CO}}\right)$ and pulmonary capillary blood volume ( $\mathrm{Vc}$ ) could be determined by the Roughton-Forster method.

$\mathrm{DL}_{\mathrm{Co}}$ kept rising as work load was increased until the pulmonary blood flow and oxygen consumption stopped going up. DLoo increased principally because of a twofold increase in Vc during exercise. $\mathrm{DM}_{\mathrm{Co}}$ increased only about $20 \%$ above the resting value.

In the three patients with mitral stenosis pushed up to their peak work loads, Vc rose to the same level as in normal subjects during exercise but did not exceed the normal upper limit. This suggests that maximal distensibility of the capillary bed in normal subjects is reached or closely approached 
at peak work loads. The maximal pulmonary capillary blood volume in the normal subjects as well as in the patients with mitral stenosis agrees closely with the anatomical estimates made by Weibel of the maximal capacity of the pulmonary capillary bed.

\section{References}

1. Johnson, R. L., Jr., W. S. Spicer, J. M. Bishop, and R. E. Forster. Pulmonary capillary blood volume, flow and diffusing capacity during exercise. $\mathrm{J}$. appl. Physiol. 1960, 15, 893.

2. Riley, R. L., R. H. Shepard, J. E. Cohn, D. G. Carroll, and B. W. Armstrong. Maximal diffusing capacity of the lungs. J. appl. Physiol. 1954, 6, 573.

3. Shepard, R. H., E. Varnauskas, H. B. Martin, H. A. White, S. Permutt, J. E. Cotes, and R. L. Riley. Relationship between cardiac output and apparent diffusing capacity of the lung in normal men during treadmill exercise. J. appl. Physiol. 1958, 13, 205.

4. Ogilvie, C. M., R. E. Forster, W. S. Blakemore, and J. W. Morton. A standardized breath holding technique for the clinical measurement of the diffusing capacity of the lung for carbon monoxide. J. clin. Invest. 1957, 36, 1.

5. Roughton, F. J. W., and R. E. Forster. Relative importance of diffusion and chemical reaction rates in determining rate of exchange of gases in the human lung, with special reference to true diffusing capacity of pulmonary membrane and volume of blood in the lung capillaries. J. appl. Physiol. 1957, $11,290$.

6. Mitchell, J. H., B. J. Sproule, and C. B. Chapman. The physiological meaning of the maximal oxygen intake test. J. clin. Invest. 1958, 37, 538.

7. Cander, L., and R. E. Forster. Determination of pulmonary parenchymal tissue volume and pulmonary capillary blood flow in man. J. appl. Physiol. 1959, 14,541 .

8. Lawson, W. H., Jr., and R. L. Johnson, Jr. Gas chromatography in measuring pulmonary blood flow and diffusing capacity. J. appl. Physiol. 1962, $17,143$.

9. Forster, R. E., W. S. Fowler, D. V. Bates, and B. Van Lingen. The absorption of carbon monoxide by the lungs during breathholding. J. clin. Invest. 1954, 33, 1135.

10. Needham, C. D., M. C. Rogan, and I. McDonald. Normal standards for lung volumes, intrapulmonary gas-mixing, and maximum breathing capacity. Thorax 1954, 9, 313.

11. Andersen, K. L. Cardiopulmonary functional capacity in healthy humans in relation to sex and age. T. norske Lægeforen. 1963, 83, 227.

12. Margaria, R., P. Cerretelli, P. Aghemo, and G. Sassi. Energy cost of running. J. appl. Physiol. 1963, 18, 367.

13. Newman, F., B. F. Smalley, and M. L. Thomson. Effect of exercise, body and lung size on CO diffusion in athletes and nonathletes. J. appl. Physiol. 1962, 17, 649.

14. Daly, W. J., S. T. Giammona, J. C. Ross, and H. Feigenbaum. Effects of pulmonary vascular congestion on postural changes in the perfusion and filling of the pulmonary vascular bed. J. clin. Invest. 1964, 43, 68.

15. Bucci, G., and C. D. Cook. Studies of respiratory physiology in children. VI. Lung diffusing capacity, diffusing capacity of the pulmonary membrane and pulmonary capillary blood volume in congenital heart disease. J. clin. Invest. 1961, 40, 1431.

16. McNeill, R. S., J. Rankin, and R. E. Forster. The diffusing capacity of the pulmonary membrane and the pulmonary capillary blood volume in cardiopulmonary disease. Clin. Sci. 1958, 17, 465.

17. Lawson, W. H., Jr., H. N. Duke, R. W. Hyde, and R. E. Forster. Relationship of pulmonary arterial and venous pressure to diffusing capacity. J. appl. Physiol. 1964, 19, 381.

18. Ross, J. C., G. E. Maddock, and G. D. Ley. Effect of pressure suit inflation on pulmonary capillary blood volume. J. appl. Physiol. 1961, 16, 674.

19. Lewis, B. M., W. T. McElroy, E. J. HayfordWelsing, and L. C. Samberg. The effects of body position, ganglionic blockade and norepinephrine on the pulmonary capillary bed. J. clin. Invest. 1960, 39, 1345.

20. Weibel, E. R. Morphometry of the Human Lung. New York, Academic Press, 1963, pp. 70-104.

21. Cotes, J. E., D. P. Snidal, and R. H. Shepard. Effect of negative intra-alveolar pressure on pulmonary diffusing capacity. J. appl. Physiol. 1960, 15, 372. 